\title{
Intergroup Relation-Based Conflict Resolution Patterns to Junior High School Students
}

\author{
Ahmad Saefulloh ${ }^{*}$, Eli Karliani ${ }^{2}$, Triyani ${ }^{3}$,Vincentius Abdi Gunawan ${ }^{4}$ iD \\ 1,2,3,4 Palangka Raya University, Palangka Raya, Indonesia \\ *Corresponding author: saefulloh@fkip.upr.ac.id
}

\begin{abstract}
Conflicts between junior high school students cannot be underestimated or left unchecked so that it drags on and causes ongoing conflicts if a settlement pattern and root cause are not found immediately. This study aims to analyze the pattern of intergroup relation-based conflict resolution carried out by junior high school students. This article is the result of research conducted using the development (R\&D) method with the stages of needs analysis, development, and testing. The data collection method was carried out by distributing questionnaires to public junior high schools randomly consisting of 799 respondents, namely 329 male and 470 female. Data processing is done by grouping student answers based on research indicators in order to obtain a conflict resolution model used by students. The results showed that the pattern of intergroup relation-based conflict resolution carried out by junior high school students and equivalent in solving problems, students were more dominant in choosing how to communicate, either through cellphones or meeting in person to discuss the root causes of the problems that occurred then reconciled by apologizing to each other, do not do violence, avoid emotions, say rude, high-pitched, to avoid fights. As for students who use violence in an effort to solve problems, it will occur if one of their friends shows opposition and resistance, has a high-pitched tone to speak harshly so that it ignites excessive emotions and causes fights.
\end{abstract}

Keywords: Conflict Resolution, Intergroup Relations

\begin{tabular}{lll}
\hline History: & & Publisher: Undiksha Press \\
Received & : May 08, 2021 & Licensed: This work is licensed under \\
Revised & : May 10, 2021 & a Creative Commons Attribution 3.0 License \\
Accepted & : June 16, 2021 &
\end{tabular}

\section{INTRODUCTION}

The many conflicts between students that are currently happening have attracted public attention to look further into the root causes of the problems. Conflicts that occur are caused by many factors including bullying (Noor et al., 2010), miscommunication (Wallace, 2019), group control (Jit et al., 2016), to the factor of pluralism (McCauley et al., 2004). The need for an in-depth study is a middle way to find a way out of resolving conflicts between students so that there is no gap between the teacher's actions and the actions of students in overcoming problems. Wrong actions will not improve the atmosphere of conflict (Yilmaz, 2009), it will cause prolonged conflict between students without finding a bright spot for solving the problem (Kranton et al., 2012). Conflicts that occur in students at Jeneponto are caused by differences of opinion, feelings of revenge in students against other students or groups of students who have abused and humiliated themselves, the desire to maintain a sense of solidarity with fellow friends in a gang, as well as misunderstandings in attitude and behavior communicate. This causes rifts in the relationship between conflicted students, disharmony between students and between parents, disruption of the learning process between conflicted students and even physical losses due to fights (Asnidar, A. Octamaya Tenri Awaru, 2015). Another more serious impact is the ongoing brawl as a result of feeling resentful and not finding a way to get along between conflicting students. This phenomena becomes important for parents and educators to find out efforts to resolve conflicts so that they are not sustainable and cause other adverse impacts, so the study in this article is important to know, namely to see the appropriate pattern of conflict resolution in dealing with 
the causes of various conflicts and the efforts made by the students themselves in resolving conflicts.

Junior high school students in the stage of development are included in the category of adolescent age (Winkjasastro, 2005). Adolescence is a period full of conflict, because at this time students experience very complex stages of change such as physical changes, behavior patterns, social roles, as well as a period of searching for identity and self-identity as an individual (Hanafi, 2015). For a teenager, this change is a situation that often causes problems and is unpleasant (Saputro, 2017), so that the problems that arise require a solution so as not to become a burden that can interfere with further development (Batubara, 2016). In addition, in schools students are required to follow the school rules and regulations that are applied in order to create an orderly, conducive, and calm atmosphere in the school environment (Jamilah, 2020). These two things become special considerations for educators and parents in fostering adolescence, because students in this category need maximum attention in terms of controlling their activities.

Junior high school students are part of the community within the scope of the world of education, that means students are also social beings who interact with other students (Aris Riswandi Sanusi et al., 2020). When interacting, there will be conflict and cooperation, thus conflict is also part of life (Khafidz Fuad Raya, 2016). Social conflict is a social process that occurs in an individual or group (Umashankar \& Charitra, 2014), In the sociological view, social conflict is a picture of the occurrence of disputes (Skordoulis et al., 2020), squabbles, tensions (Böhm et al., 2021), or conflicts as a result of differences that arise in people's lives. (Zulkifli et al., 2020). These differences can be due to individual differences or in the form of group differences which include differences in views, understandings, interpretations, interests that affect the student's environment. These differences show that students are social beings so that conflicts can arise (Rahmana, 2018).

Based on the background of the emergence of the above conflicts caused by these differences, this study aims to analyze the pattern of intergroup relation-based conflict resolution carried out by junior high school students in East Java province. The novelty of this study is to see the conflict resolution model carried out by junior high school students in East Java Province through the Intergroup Relations approach.

\section{MATERIALS AND METHODS}

This study uses development research (R\&D) methods with the stages of needs analysis, development, and testing. The result to be achieved is to analyze and map conflict resolution efforts based on the socio-cultural background of junior high school students. The instrument used is a questionnaire through conflict resolution indicators by looking at communication patterns in intergroup relations which are built based on the social conflict theory proposed by Lewis A. Coser. According Coser, conflicts that occur in society do not merely show a negative function. However, conflict can also have a positive impact. Conflict is a way or tool to maintain, unite, and reinforce the existing social system. For example, the positive function of conflict in matters concerning the dynamics of intergroup relations, with out groups based on communication, emotion, discussion, help from others and resolution by means of violence. From this indicator, it will be seen which pattern of presentation is more dominantly used by junior high school students in East Java in solving their problems. The data collection method was carried out by distributing questionnaires to public junior high schools in East Java randomly consisting of 799 respondents, namely 329 male and 470 female. The characteristics of the respondent shown in Table 1. Data processing is done by grouping students' answers based on research indicators in order to obtain a conflict resolution model used by students in solving problems with their friends. 
Table 1. The Characteristics of Respondent

\begin{tabular}{|c|c|c|c|}
\hline NO & IDENTITY & TOTAL NUMBER & EXPLANATION \\
\hline 1 & $\begin{array}{l}\text { Gender } \\
\quad \text { - Male } \\
\text { - Female }\end{array}$ & $\begin{array}{l}329 \\
470\end{array}$ & $\begin{array}{l}\text { Number of Respondents } \\
799\end{array}$ \\
\hline 2 & $\begin{array}{l}\text { Class } \\
\qquad \begin{array}{l}- \text { VII } \\
- \text { VIII } \\
\text { - IX }\end{array}\end{array}$ & $\begin{array}{l}128 \\
361 \\
310\end{array}$ & $\begin{array}{l}\text { The majority of class VIII } \\
\text { who fill }\end{array}$ \\
\hline 3 & $\begin{array}{l}\text { Religion } \\
\quad \text { - Islam } \\
\text { - Kristen Protestan }\end{array}$ & $\begin{array}{c}797 \\
2\end{array}$ & Mayority of Islam \\
\hline 4 & $\begin{array}{l}\text { Tribe } \\
\qquad \begin{array}{l}\text { - Madura } \\
\text { - Java } \\
\text { - Malay } \\
\text { - Sunda } \\
\text { - Other }\end{array}\end{array}$ & $\begin{array}{c}716 \\
78 \\
3 \\
1 \\
2\end{array}$ & $\begin{array}{l}\text { Dominant Madurese, then } \\
\text { Java in } 3 \text { Random Schools } \\
\text { (SMPN } 1 \text { Pamekasan, } \\
\text { SMPN } 2 \text { Pamekasan, } \\
\text { SMPN } 6 \text { Pamekasan) }\end{array}$ \\
\hline 5 & $\begin{array}{l}\text { Frequently Used Social } \\
\text { Media } \\
\text { - WhatsApp } \\
\text { - Instagram } \\
\text { - Telegram } \\
\text { - Facebook } \\
\text { - Twitter } \\
\text { - Other }\end{array}$ & $\begin{array}{c}473 \\
277 \\
82 \\
28 \\
21 \\
11\end{array}$ & $\begin{array}{l}\text { One student can have } \\
\text { more than one social } \\
\text { media }\end{array}$ \\
\hline
\end{tabular}

\section{RESULTS AND DISCUSSION}

\section{Results}

Based on the open instrument distributed to students in East Java Province, it was found that the pattern of intergroup relations conflict resolution used was as shown in Figure 1. In previous studies, it was explained that the cause of conflicts between junior high school students that led to relationship damage, fights and physical losses was because students did not get the expected justice, so in an effort to take conflict resolutions in accordance with these expectations, the authors conducted information mining on students the steps that were taken. often taken when students are involved in conflict, so that this effort becomes a reference for teachers and parents to choose alternative solutions that can be taken. Based on the Coser indicator above, it is obtained a picture of which pattern is dominantly used by junior high school students in East Java in solving the problem. Figure 1 shows that there are at least 13 ways that students do in solving their problems with friends, be they friends in the school environment or outside of school. 


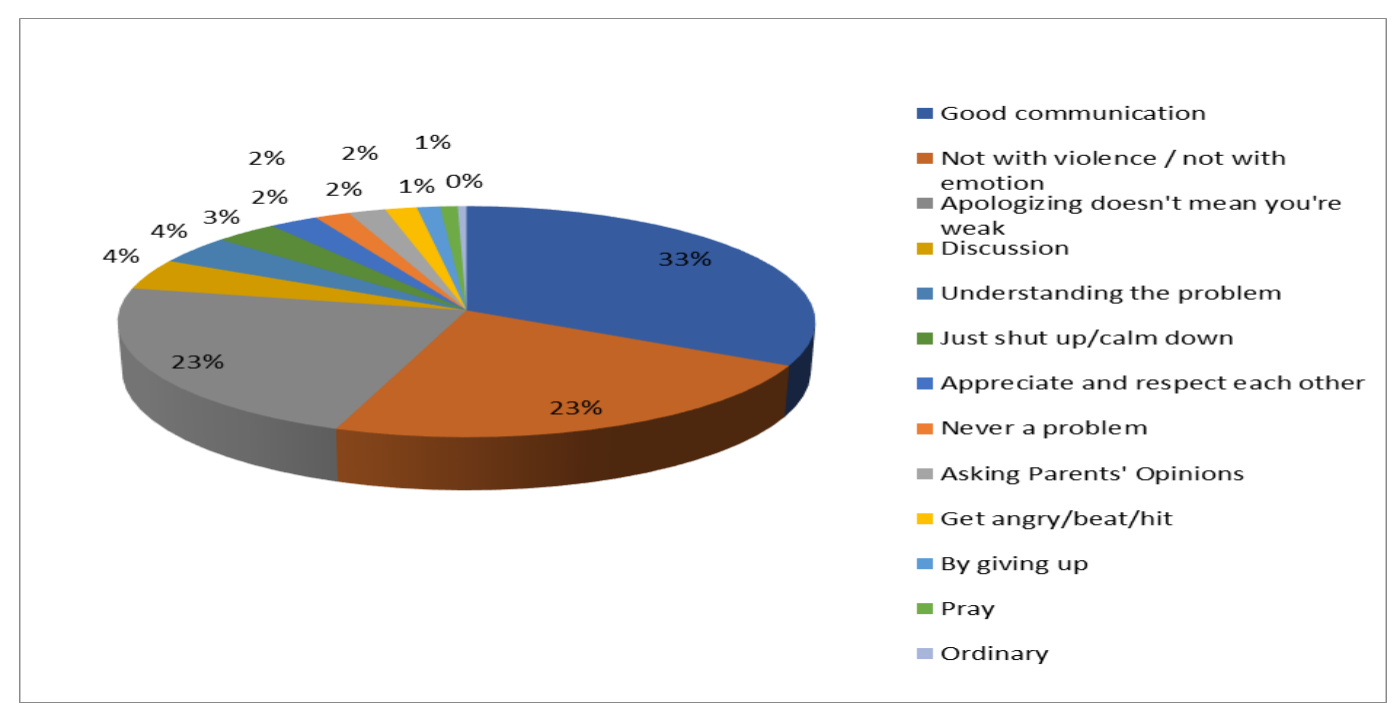

Figure 1. Students Response About How to Solve Problems by Students

\section{Good communication}

As many as $33 \%$ of students stated that in solving problems with their relations or friends by communicating well. In this case, students prefer to meet friends who are involved in the problem and then discuss well to find a solution to the problem. The author sees that the form of communication made by students can be through messages or talk directly via cellphones and meet in person. The reason students choose this method is to find out directly the root of the problem that occurs so that there is no misunderstanding. After meeting and talking well, peace is made with one of the students apologizing first or forgiving each other. This method is more dominantly chosen by junior high school students because errors that appear often occur and repeat, so that it has become a problem that often occurs. In its application, good communication is done by holding back emotions and respecting differences of opinion to get a solution to make peace.

\section{Not with violence / not with emotion}

As many as $23 \%$ of students stated that in solving problems by not using violence. In this case, the writer sees that the violence is not meant by not venting emotions when meeting to talk about the problems they are experiencing. Students tend to choose to avoid violence on the grounds that improving friendships is much better than settling protracted problems that actually make the atmosphere uncomfortable, whether it is when they meet in class or outside of class. Moreover, if the friend involved in the problem is a close friend who lives close to the house. The author also sees that not by violence in this case means not through physical fights or persecution. This method is more about choosing to give in and considering the risks that arise if it is done with violence, students tend to think positively by finding a way out of speaking well without showing resistance or conflict that causes tension and fights that trigger excessive emotions.

\section{Apologize}

Apologizing to friends first is a student's choice in solving problems with friends, as many as $23 \%$ of students answered to apologize to friends involved in the conflict. The form of apology made by students by sending messages via cellphone, communicating via cellphone, and meeting the friend directly. Among the media that is often used by students is to use communication via mobile phones. Efforts to apologize made by one of the students involved often get a good response immediately, so that the students involved in the problem 
can find a way out by making peace and forgiving each other. However, some students stated that they felt relieved if they had apologized, regardless of whether the apology would be accepted or not. But in general it can be concluded that the students' efforts in solving problems with their friends by apologizing in advance with the aim that friendships return to normal.

\section{Deliberation}

Deliberation is also the choice of some students in solving problems, as many as $4 \%$ of students choose to conduct deliberation. In this case the deliberation in question is to discuss directly either through mobile phone communication or meet directly the parties involved in the problem and then convey the reasons for each student who is the cause of the conflict. When the deliberation took place, it was not uncommon for debates and arguments between the students involved, but after all of them conveyed the feelings they felt, the students understood the causes of the conflict. Deliberations were carried out by presenting intermediary students as mediators, but some students answered that only the parties involved attended. In the results of the survey, it was found that after the deliberation meeting the conditions of friendship returned to being good, because each student knew the cause of the problem and understood that there would be problems again if he repeated the cause. In this way, the writer sees that there are students who think the conflict has been resolved, and there are students who feel that the problem has not been resolved. So, the author sees that students who have not finished will have an impact on activities at school so that problems will be resolved by the school either through the homeroom or the Counseling Guidance teacher.

\section{Understand the problem that occurs}

A number of students choose to understand the problems that cause conflict as much as $4 \%$. Understanding the problem in this case the author sees that students do not immediately commit violence, and do not immediately apologize but rather wait for the right time to make peace. Students choose to remain silent and let the problems that occur go away by themselves. The author sees that this method is usually done by students who often have minor conflicts in their relationships, whether through speech or attitude. Slowly the condition will become normal inadvertently. However, some of the student answers the author analyzes that understanding the problem is done by discussing the causes of the conflict directly and stating that he feels offended by the words or actions of his friend, and conveys it well and politely so as not to cause further conflicts.

\section{Calm down or just shut up}

Students also choose to calm themselves by staying silent when there is a conflict with friends. As many as $3 \%$ of students choose this method because it is considered that one day things will return to normal. In this case the author sees a strong ego so that students prefer to be silent. On the one hand, students avoid quarrels, but on the other hand the conflict does not end immediately because there are students who do not immediately apologize. In other students' answers, the writer found that silence meant avoiding the place of conflict, then calming down by joining other students or choosing to be alone.

\section{Respect differences and respect each other}

As many as $3 \%$ of students choose to use conflict resolution methods by respecting and respecting differences of opinion that occur. This attitude the writer finds in the sense that to avoid quarrels, students prefer to remain silent so that the debate does not continue which results in a fight, so that the opponent of the debate will stop and the atmosphere will not drag on. In addition to speaking well, the author finds that the way to appreciate the 
differences is expressed by apologizing and then asking the cause of the problem so that it does not cause conflict in the future. The way to appreciate it is to control emotions by believing that there are differences between them that cannot be forced, so they prefer to appreciate by looking at the problem from a different perspective, not only from their own point of view to avoid imposing their own ego. The author concludes that expectations of respecting differences are carried out by students in various ways.

\section{Ask parents or teachers for their opinion}

Some students choose conflict resolution methods through asking parents or teachers to help solve problems they face as much as $2 \%$. In this step, the writer sees that students want the mediator of the problematic parties to come from more mature people such as parents or teachers. Teachers and parents play a role as a giver of advice and input, not as a substitute for students with problems directly. The author sees that students who choose this method because they are accustomed to telling their parents what is happening to themselves in the school environment, and parents actually suggest that these problems can be conveyed to the school counselor and counselor to mediate so that the root of the problem can be identified. find. On the other hand, students who choose this method so that they get attention from other parties and to avoid friends who do not agree with them are involved in the problems that occur. In this case the author concludes that solving student problems by asking for opinions from teachers or parents is a safe way for students to avoid disputes with other friends who are not involved in the root cause of the problem.

\section{Angry/beat/hit}

As many as $2 \%$ of students choose how to solve problems by getting angry to fighting/fighting. The author sees this method is done by students if one student continues to oppose showing an attitude of resistance. One of the students' answers would be to choose this method if the friend involved in the problem talks a lot, is rude, continues to challenge, gets bullied, and doesn't apologize. So that the ego arises that problem solving cannot be done by speaking well, but with physical strength so that the opponent of the conflict knows the courage he has. One of the other reasons the author finds that this method is chosen by students who have a hard character (bad students) who often show their delinquent attitude in front of other students, the author sees that the chosen attitude is a form of expression to get recognition from friends who have problems or other friends that he is the ruler or champion of the class, so the expression of solving problems is through fighting. In this case the author concludes that this method is done by students when one student says rudely, shows resistance and does not show good faith to solve problems or comes from students who feel themselves as rulers (thugs) in the conflict environment (school or outside school)

\section{Never had a problem}

As many as $2 \%$ of students stated that they had never had problems with friends. The author sees in this answer that students prefer to avoid quarrels and assume that debates and quarrels that occur are not a problem. Students who choose this method are students who are relaxed in making friends and can put emotions aside.

\section{Beat}

Students stated that they prefer to give up in conflict resolution by $1 \%$. This attitude was chosen by students on the grounds that they did not want to be bothered by the occurrence of problems. In addition to respecting differences, there is also an indifferent factor by ignoring the occurrence of debates or fights. The author sees that the attitude of surrender is meant by students by apologizing in advance and making peace not to continue 
the fight. On the other hand, the writer sees that giving in is meant not to show excessive emotion by controlling speech so as not to offend and be rude. The author sees students who choose this method trying to express themselves with patience by apologizing first. Giving in to other students' choices revealed that by not forcing their will, listening to opinions, thinking positively, waiting for the right time to apologize, thinking before acting, and understanding the conditions of the fight.

\section{Pray}

Praying which is meant in this case is that students prefer introspection and submit problems that occur to Allah SWT by stating that the problems will end soon. Praying in another sense, the author finds that this method is an effort for students who have protracted problems and do not ask parents or teachers for opinions, these students choose that in time the problem will be resolved. Students in this category are more dominant in being silent in everyday life, they are not able to express words when there is a conflict but are lost in feelings so that they hope that the problem will be resolved by itself. The attitude shown by students in this category tends to be calm and behave the same to all friends, the writer sees that students are more dominant in being shy. In the results of the survey the authors found as many as $1 \%$ of students who chose how to pray in resolving conflicts with friends.

\section{Ordinary}

Ordinary in the sense of not considering quarrels or debates as things that cause problems, more inclined to an indifferent attitude. In the answers of other students, the writer sees that this ordinary attitude is an expression of students' expressions of not wanting to be burdened with life with things that touch with feelings. So the author concludes that the ordinary attitude chosen by students is a student who is indifferent to the environment, and as many as 3 students chose the answer.

\section{Discussion}

A sense of injustice is one of the factors that trigger conflicts in society, especially among students (Faturrochman, 2006, hal. 99). The main factor in the emergence of a sense of injustice is the non-fulfillment of expectations that they think should be fulfilled. This feeling of injustice arises when people compare themselves with the circumstances of others around them. For example, a brawl conflict is a process of attacking or fighting each other which is carried out in groups and occurs between one group and another because there is a problem. Conflicts that cause brawls know no age, they are teenagers, adults, even minors. The most common brawl conflicts are brawls among schools or brawls between students (Smith \& Mazzarella, piele, 2011).

Conflict is a common phenomenon, however, it still requires resolution so that the impact does not spread. Various approaches are taken in an effort to resolve conflicts such as the Cross-Cultural Psychology approach. This approach in resolving conflict needs to consider the patterns of each culture, because these patterns have become habits and are difficult to break, such as the patterns of accommodation, avoidance, competition, and collaboration. (Andrlanto, 2002). This approach is in order to create safe and peaceful conditions in order to create a harmonious community environment so it is necessary to create a system that regulates human life and its groups. The system can be in the form of special rules, laws, norms, or the concept of the minds of most citizens about things that society considers to have high value. (Koentjaraningrat, 1987). Those who violate the system in general will receive social sanctions, otherwise those who comply will get recognition as group members, receive respect and a good place in society. The consequences of compliance and non-compliance make people try to adjust themselves by acting and behaving in line with 
the prevailing system. According to Triandis, attitudes and behaviors that are important in a social environment are conflict resolution, social distance, helpful behavior, domination, cooperation, obedience, and openness..

Historically, the Indonesian nation is actually not a "social-conflict-free" nation. The ups and downs and the expansion of the government power of the Hindu (such as Majapahit) and Islamic (Mataram) kingdoms in the archipelago were very thick with the strategy of social conflict which even became their mode of struggle. The history of the modern national movement initiated by Budi Utomo is also very thick with the scent of struggles and classconsciousness between the colonized and the colonialist (the Netherlands). The year 1945 was the highest milestone for conflictual processes marked by the birth of the Unitary State of the Republic of Indonesia through struggles and conflict journeys that were very tiring and took many victims. Even today, social conflicts continue to occur repeatedly and continuously replicate themselves from one place to another in various forms throughout Indonesia (Varshney, 2004). Seeing the processes of social conflict that have been embedded in history and continue to be "refreshed" in the memory of every citizen through the media of information and education, social conflict in Indonesia is not really a "new and strange thing". It just changes shape and spirit. In general, the tendency for social conflict to occur in "Certain Regions" follows the trend in Indonesia. Meanwhile the pattern of social conflict (form, background or root cause of conflict, depth, and scale of conflict) is not much different (Malik, 2003).

Critical issues that frame social conflicts that are often encountered in social systems (at all levels) are First Conflicts between social classes (social class conflict) as occurs between the "working class" against the "employer class" in industrial-relationship conflicts, or the "landlords" against the "labor-peasant class" in agrarian conflicts. Second, Modes of production conflict (mode of production conflict in the economy) that takes place between groups of economic actors with a peasantry-traditionalism (small-scale subsistence-simplescale) economy against economic actors with a moral-economic basis of profit accumulation and exploitation. Third, Natural resource conflict and the environment (natural resources conflict) is a social conflict centered on the issue of "claim and reclaiming" the control of natural resources (land or water) as the most important dispute. In many ways, natural resource conflicts coincide with agrarian conflicts, in which a group of people fight for land tenure rights that are claimed as their property against the state, private bodies or other social groups. Fourth, Ethnic and racial conflicts that carry differences in skin color and subcultural attributes attached to the skin color of the disputing parties. Fifth, Conflicts between religious adherents (religious conflict) that take place because each party sharpens the differences in principles inherent in the teachings of each religion they embrace. Sixth, Sectarian conflict, is a conflict triggered by differences in views or ideologies held by the parties. Conflict will further sharpen differences in views between schools (often on the same ideology) (Marpuah, 2014). Seventh, Political conflict that takes place in the dynamics of power exercise. Eighth, Gender conflict is a conflict that takes place between two adherents of different views with the basis of difference being gender. The parties carry different and conflicting interests (politics, power, economy, social roles) between two opposing support groups (Mustain, 2013). Ninth, Conflicts between communities (communal conflicts), which can be caused by various factors, such as: the existence of the cultural identity of the community and factors of life resources (sources of sustenance). Communal conflicts can often develop into territorial conflicts if each group identity is attached to the identity of the area Territorial conflict is a social conflict launched by the community or local community to defend the area where they have built their lives so far (Nutfa \& Anwar, 2015).

Territorial conflicts are often found in Forest Concession Rights (HPH) areas, where indigenous/local communities feel threatened for their source of life and socio-cultural 
identity when HPH authorities destroy trees and forests where they have been sheltering and foster socio-cultural and socio-community life. This are First, Inter-state conflict is a conflict that takes place between two countries with different interests, ideologies and economic systems and conflicting interests with other parties (Tidore, 2020).

In a global trend, inter-state conflicts can develop into regional conflicts as happened in the era of the "cold war" (Soviet Union vs. USA Block), or the war in the Balkans in the late 1990s, where the USA and NATO killed Serbia (Bebbington, 1997). If viewed from the perspective of the speed of reaction given by the parties to the disagreements formed among the conflicting parties, then social conflict can take place in several variations of types/forms (Tadjoeddin, 2006), that is: peaceful collective action that takes place in the form of opposing actions, which can take the form of: "corrective action", "strike", "eat strike", and "silent action". In the event that a satisfactory conflict resolution is not found, it is possible for peaceful actions to develop into "strikes and civil disorders" in the form of demonstrations or riots (Amrullah et al., 2018); demonstrations or protest gatherings are activities that express the disagreements shown by a group on a particular issue. The degree of conflict pressure is roughly equal to that of a strike. Collective action like this is usually taken as a reactionary protest carried out in groups or in bulk over the disagreements shown by a certain party to the opposing party on a certain issue. Usually the scale is localized, sporadic (although it is possible to expand) (Istiqomah \& Widiyanto, 2020); riots and riots (riots), are an increase in the degree of violence from mere demonstrations. The riots took place as a mass reaction to a general unrest. Because it is accompanied by mass hysteria, riots can often not be controlled easily without causing injuries (even death) (Dharmariza et al., 2020); rebellions are prolonged social conflicts that are usually initiated and planned more constructively and well organized. Rebellion can involve the struggle for sovereignty or defending "areas" including the existence of certain ideologies (Kamim et al., 2018). Rebellion does not have to take place manifestly, but can be started "under the ground" so that it looks latent in nature; radical-revolutionary actions (revolutions) are opposing movements that want rapid social change in a certain situation; war is a form of conflict between countries that is highly undesirable by the world community because of its very broad impact on humanity.

\section{CONCLUSION}

The pattern of intergroup relation-based conflict resolution carried out by junior high school students is equal in solving problems, students are more dominant in choosing how to communicate, discussing between parties with problems either through communication via cellphone or meeting in person to discuss the root cause problems that occur then make peace by apologizing to each other. The next method chosen by students is not to do violence, the application of this method is that students avoid emotions, say rude, high-pitched words, to avoid fights. The next dominant way is to apologize first to friends who are involved in the problem, discuss the root cause of the problem, understand differences, ask for opinions from parents or teachers, relent and pray. As for students who use violence in an effort to solve problems, it will occur if one of their friends shows opposition and resistance, has a highpitched tone to speak harshly so that it ignites excessive emotions. The weakness of this pattern is that conflicts will recur in the future, because there is no deterrent effect, especially for students who tend to resolve conflicts by means of physical violence, so that the pattern of conflict resolution is continued through police development so that it has a deterrent effect and does not cause prolonged conflicts in the future. 


\section{ACKNOWLEDGMENTS}

The author would like to thank LPDP through the Productive and Innovative Research Program (RISPRO) Batch I Year 2020 which has funded this research so that the article is published. Furthermore, to all parties from the University of Palangka Raya LPPM as the original institution of the Writing Team and the Palangka Raya City Education Office who supported all of these research activities.

\section{REFERENCES}

Amrullah, A., Muslim, M., Nurhidayati, S., Noviati, W., \& Salahuddin, M. (2018). Kecerdasan Budaya Dalam Proses Pencegahan dan Resolusi Konflik di Kabupaten Sumbawa. DIALEKTIKA: Jurnal Ekonomi Dan Ilmu Sosial, 3(1). https://doi.org/10.36636/dialektika.v3i1.88.

Aris Riswandi Sanusi, Maftuh, B., \& Malihah, E. (2020). Upaya pembentukan karakter kepemimpinan lintas budaya dalam membangun kemampuan resolusi konflik generasi milennial. Jurnal Ilmiah Mimbar Demokrasi, 20(1). https://doi.org/10.21009/jimd.v20i1.15661.

Asnidar, A., \& Awaru, A. O. T. (2017). Konflik Antar Pelajar (Studi Kasus Siswa Sma Negeri 8 Jeneponto). Jurnal Sosialisasi: Jurnal Hasil Pemikiran, Penelitian dan Pengembangan Keilmuan Sosiologi Pendidikan, 4(2), 55-61. https://doi.org/10.26858/sosialisasi.v0i0.11787.

Bebbington, A. (1997). Social Capital and Rural Intensification: Local Organizations and Islands of Sustainability in the Rural Andes. Geographic Journal,163(2), 189-197. https://doi.org/10.2307/3060182.

Batubara, J. R. (2016). Adolescent Development (Perkembangan Remaja). Sari Pediatri, 12(1). https://doi.org/10.14238/sp12.1.2010.21-9.

Böhm, R., Fleiß, J., \& Rybnicek, R. (2021). On the Stability of Social Preferences in InterGroup Conflict: A Lab-in-the-Field Panel Study. Journal of Conflict Resolution, 65(6). https://doi.org/10.1177/0022002721994080.

Dharmariza, M., Hidayat, R., \& Widhagdha, M. F. (2020). Pemberdayaan Masyarakat Sebagai Strategi Resolusi Konflik Sosial. Jurnal Kebijakan Publik, 11(1). https://doi.org/10.31258/jkp.11.1.p.1-6.

Faturrochman. (2006). Pengantar Psikologi Sosial. Pustaka

Hanafi, M. (2015). Konsep Dasar dan Perkembangan Teori Manajemen. Managemen, 1(1).

Hurlock, T. H. (2003). Manajemen. BPFE Yogyakarta

Istiqomah, A., \& Widiyanto, D. (2020). Resolusi konflik berbasis budaya Tionghoa dan Jawa di Surakarta. Jurnal Civics: Media Kajian Kewarganegaraan, 17(1). https://doi.org/10.21831/jc.v17i1.28754.

Jamilah, J., \& Mulyadi, M. (2020, September). Dampak Pembelajaran Daring di Tengah Pandemi COVID 19 pada Siswa Sekolah Dasar. In Prosiding Seminar Nasional Pendidikan Biologi. http://researchreport.umm.ac.id/index.php/psnpb/article/view/3641.

Jit, R., Sharma, C. S., \& Kawatra, M. (2016). Servant leadership and conflict resolution: A qualitative study. International Journal of Conflict Management, 27(3), 591-612. https://doi.org/10.1108/IJCMA-12-2015-0086.

Kamim, A. B. M., Amal, I., \& Khandiq, M. R. (2018). Dilema pemetaan partisipatif wilayah masyarakat adat di Indonesia: upaya resolusi konflik agraria dan kritiknya. Prosiding Senaspolhi, 1(1). https://publikasiilmiah.unwahas.ac.id/index.php/SENASPOLHI/article/view/2435.

Khafidz Fuad Raya, M. (2016). Resolusi Konflik dalam Institusi Pendidikan Islam (Kajian 
Empirik dan Potensi Riset Resolusi Konflik). Jurnal Pendidikan Islam Indonesia, 1(1). https://doi.org/10.35316/jpii.v1i1.38.

Koentjaraningrat. (1987). Kebusayaan Mentalitas dan Pembangunan. PT Gramedia.

Kumolohadi, R., \& Andrianto, S. (2002). Resolusi Konflik dalam Perspektif Psikologi Lintas Budaya. Psikologika: Jurnal Pemikiran dan Penelitian Psikologi,7(13), 5-13. https://doi.org/10.20885/psikologika.vol7.iss13.art1.

Malik, I. e. (2003). Menyeimbangkan Kekuatan: Pilihan Strategi Menyelesaikan Konflik atas Sumberdaya Alam. Yayasan Kemala.

Mustain, M. (2013). Segregasi Etno-Religius: Upaya Resolusi Konflik Dan Pembangunan Perdamaian. Walisongo: Jurnal Penelitian Sosial Keagamaan, 21(1). https://doi.org/10.21580/ws.2013.21.1.237.

Noor, M., Brown, R., Taggart, L., Fernandez, A., \& Coen, S. (2010). Intergroup Identity Perceptions and their Implications for Intergroup Forgiveness. The Irish Journal of Psychology, 31(3-4). https://doi.org/10.1080/03033910.2010.10446332.

Rahmana, Z. S. (2018). Resolusi Konflik Sosial Keagamaan Di Kota Bandung. Religious: Jurnal Studi Agama-Agama Dan Lintas Budaya, 2(2). https://doi.org/10.15575/rjsalb.v2i2.3105.

Saputro, K. Z. (2018). Memahami ciri dan tugas perkembangan masa remaja. Aplikasia: Jurnal Aplikasi Ilmu-ilmu Agama, 17(1), 25-32. https://doi.org/10.14421/aplikasia.v17i1.1362.

Skordoulis, M., Liagkis, M. K., Sidiropoulos, G., \& Drosos, D. (2020). Emotional intelligence and workplace conflict resolution: The case of secondary education teachers in greece. International Journal of Research in Education and Science, 6(4). https://doi.org/10.46328/ijres.v6i4.1224.

Smith \& Mazzarella, piele. (2011). Masalah konflik. PT. Rineka citra.

Tadjoeddin, M. Z. (2006). A Future Resource Curse in Indonesia: The Political Economy. UNDP.

Umashankar, K., \& Charitra, H. (2014). Conflict Resolution Through Training on Emotional Intelligence and Empathy in a Workplace-An Empirical Study. Research in Business and Management, 1(2). https://doi.org/10.5296/rbm.v1i2.5865.

Wallace, W. C. (2019). Conflict and Conflict Resolution. In The Palgrave Encyclopedia of Global Security Studies. https://doi.org/10.1007/978-3-319-74336-3_16-1.

Varshney. (2004). Indonesian Collective Violence Database . United Nation.

Yilmaz, M. E. (2009). The social identity dimension of inter-group conflicts. Bogazici Journal, 23(1-2). https://doi.org/10.21773/boun.23.1.5.

Maftuh, B., \& Malihah, E. (2020). Pendidikan Multikulturalisme Sebagai Resolusi Konflik: Perspektif Pendidikan Kewarganegaraan. Jurnal Pendidikan Politik, Hukum Dan Kewarganegaraan, 10(2). https://jurnal.unsur.ac.id/jpphk/article/view/1049. 